\title{
Nalbuphine Hydrochloride
}

National Cancer Institute

\section{Source}

National Cancer Institute. Nalbuphine Hydrochloride. NCI Thesaurus. Code C47629.

The hydrochloride salt form of nalbuphine, a synthetic phenanthrene opioid with opiate agonist and antagonist effects, used to treat moderate to severe pain and provide preoperative and postoperative analgesia and sedation. Nalbuphine hydrochloride binds to kappa-, mu- and delta-opioid receptors but not to sigma-opioid receptors. This opioid exerts its analgesic actions primarily through kappa-opioid-receptor agonism and partially through mu-opioid receptor agonism. 